\title{
リドカイン静注による蝸電図の変化について
}

\author{
五十嵐良和・麻生伸・大井 秀哉 \\ 上田 晋介・渡辺 行雄・水越 鉄理
}

\section{Electrocochleographic Changes Following Intravenous Administration of Lidocaine Hydrochloride}

\author{
Yoshikazu Igarashi, Shin Aso, Hideya Ohi, Shinsuke Ueda, \\ Yukio Watanabe and Kanemasa Mizukoshi \\ (Toyama Medical and Pharmaceutical University)
}

\begin{abstract}
Compound action potentials (APs) in electrocochleography were recorded after intravenous administration of lidocaine hydrochloride in guinea pigs $(10-20 \mathrm{mg} / \mathrm{kg})$ and in patients with tinnitus $(2 \mathrm{mg} / \mathrm{kg})$. In other patients with tinnitus, blood samples were collected for measurement of the serum concentration level of lidocaine. Blood pressure and pulse rates were monitored following adminstration $(1 \mathrm{mg} / \mathrm{kg})$. Changes in the amplitude of APs were observed.

In guinea pigs, AP amplitudes were significantly reduced just after injection of lidocaine and then increased until 4 minutes after administration, gradually decreased later. In patients with tinnitus no significant changes in AP could be seen. The maximum serum concentration level of lidocaine was $2.26 \pm 0.68 \mu \mathrm{g} / \mathrm{ml}$ at 2 minutes after administration and then it was rapidly decreased. No changes could be seen in blood pressure or pulse rate.
\end{abstract}

Key words: lidocaine, compound action potential, electrocochleography

はじめに

リドカイン静注による耳鳴の治療は Bárány (1935) が局所麻酔剂静注の有効性を報告1)して 以来多くの研究がなされて扣り, 本邦において も安田らの報告）を初めとして近年多くの報告 がなされ耳鳴治療全体に再び注目を集める契機 となっている、リドカインの耳鳴抑制機序の問 題は耳鳴の発現機序そのものにも大きく関与 し, 中枢抑制説から末梢抑制説まで多くの報告 がみられるが，定説を見るに至っていないのが 現状である。この中で Melding ${ }^{8)}$, Shea ${ }^{10) 11), ~}$
Goodey ${ }^{12)}$, Emmett ${ }^{13) 14)}$ らは聴神経系の異常な neuronal hyperactivity を原因とするコルチ器 障害性耳鳴に対してリドカインが有効であると の説を唱え，さらに Englesson (1976)18) はこの 説を裏付けるよらに ${ }^{14} \mathrm{C}$ でラベルしたリドカイ ンがラットの蝸牛軸に蓄積することを報告し， リドカインが聴覚路末梢で作用する可能性を示 唆した。

今回は上述のような背景をもとに，リドカイ ンの蝸牛神経に対する影響を調べる目的でモル モットと耳鳴患者でリドカイン静注後の蝸電図 
AP の測定を行なった。また循環系への影響を 調べる目的で耳鳴患者で静注後の静脈血漿中リ ドカイン濃度と血圧, 心拍数を経時的に測定し た. 以上の結果について若干の文献的考察を加 光て報告する。

\section{対象と方法}

1）モルモットの蝸電図 AP 測定

プライェル反射良好な $300 〜 500 \mathrm{~g}$ の白色モル モット23匹を用いた。 ネンブタール $30 \mathrm{mg} / \mathrm{kg}$ を腹腔内に投与し，浸潤麻酔下に気管切開術を 施行した。血管留置用カテーテルを気管内に挿 入し固定した後，パンクロニウム $1 \mathrm{mg} / \mathrm{kg}$ を 大腿部に皮下注して不動化し，人工呼吸器で調 節呼吸を行なった。右または左頸静脈に切開を 加えシリコンカテーテルを挿入し，これを薬剤 投与に用いた．腹側から中耳骨胞を開放し，針 電極の鈍にした先端をマイクロマニピュレー ターで蝸牛殼の基底回転前庭階骨壁に固定し た26)27)。蝸電図の波形が安定したのを確認し
波形を記録したのち，リドカインのグルコース 溶解液またはグルコース液単独を 10 秒で投与し， 投薬 1 分後から 10 分後まで 1 分ごとに蝸電図を 測定記録した。リドカイン投与群（17匹）には 10-20 mg/kg の比較的高濃度の静注用リドカイ ンを20\%グルコースで倍量に希釈したものを投 与し，対照群（6匹）にはリドカイン投与群と 体重あたり同容量の $20 \%$ グルュースを投与した.

蝸電図は DA-502A（ダナ・ジャパン）によ り最大刺激音圧 $100 \mathrm{dBSPL}$ の $4 \mathrm{KHz}$ サイン 1 波クリック音をスピーカーから開放系で与光， 加算器は ATAC-350S (日本光電) を使用し,

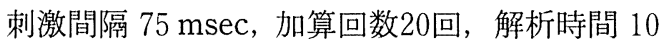
msec，時定数 $0.03, \mathrm{HCF} 3000 \mathrm{~Hz}$ に設定した.

2) 耳鳴患者の蝸電図 AP 測定 当科耳鳴外来を受診した耳鳴患者10名（男 7 名, 女 3 名）に対し， $20 \%$ グルコース $20 \mathrm{ml}$ に 静注用リドカイン $2 \mathrm{mg} / \mathrm{kg}$ (通常投与量の倍の 濃度）を溶解した液を 1 分間で静脈内に投与し，
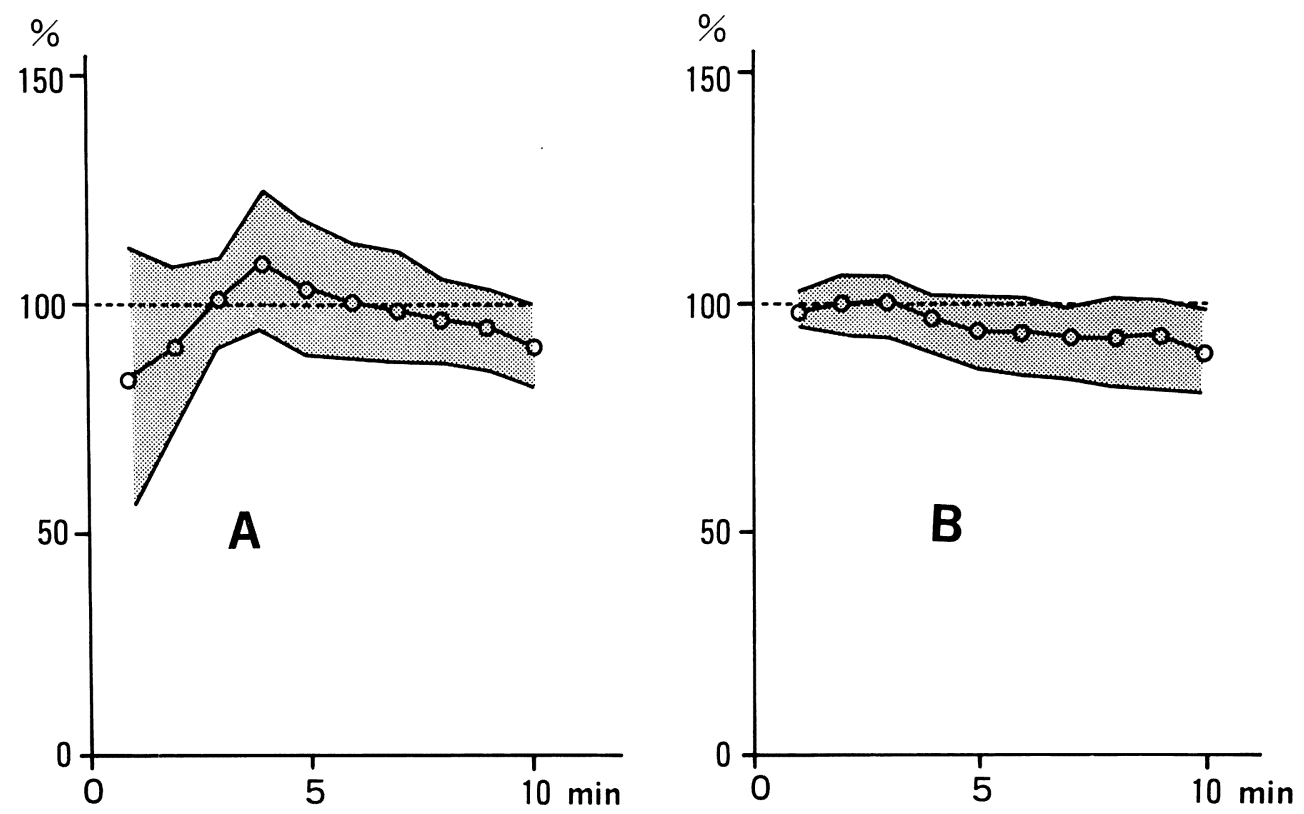

図 1 モルモットの䖮電図 AP 振幅

静注前值を $100 \%$ とした相対的変化を示した。

$\mathrm{A}$ : リドカイン $10 \sim 20 \mathrm{mg} / \mathrm{kg}+20 \%$ グルコース静注群

B : $20 \%$ グルコース静注群 (対照群) 
全例で静注前, 静注 1 分後, 10 分後に蝸電図 AP を測定記録した。また一部の症例では静注 20 分後まで 1 分ごとの測定と静注時の耳鳴変化 の聴取を行なった。

蝸電図は鼓室内誘導で測定し, 刺激音は最大 $100 \mathrm{dBSPL}$ の $4 \mathrm{kHz}$ サイン 1 波のクリック音 をスピーカーから開放系で与えた。加算機は ATAC-210 (日本光電) を使用し, 加算回数 250 回, 解析時間 $10 \mathrm{msec}$, 時定数 $0.03, \mathrm{HCF}$ $3000 \mathrm{~Hz}$ に設定し，制御およびデータ分析は NEC 製 PC-9801 を使用して当科で開発したコ ンピュータシステム28)により行なった.

3）耳鳴患者の静脈血漿中リドカイン濃度,

IIII圧，心拍数の測定

当科耳鳴外来の患者 10 名に対し，検査目的を 十分に説明し了解を得た上で静注用リドカイン $1 \mathrm{mg} / \mathrm{kg}$ を20\%グルコース $20 \mathrm{ml}$ に溶解した液 を 1 分間で静注し, 静注 2 分後, 5 分後, 10 分 後，20分後に静注血漿中リドカイン濃度，血圧， 心拍数を測定した。

\section{結 果}

1) モルモットの螖電図 AP (図 1 )

リドカイン静注前を $100 \%$ とした相対的な変 化を検討した。 AP 振幅はリドカイン投与群 （17匹）では静注直後に平均 $20 \%$ 程度有意に減 少し $(\mathrm{P}<0.05)$ ，その後逆に 4 分後をピークと して 7 分後まで平均 $10 \%$ 程度増加する傾向を認 めた $(\mathrm{P}>0.05)$. 一方, $20 \%$ グルコースを投与. した対照群（6匹）は静注後緩やかな減少のみ

表 1 耳鳴患者の原疾患と耳鳴変化

\begin{tabular}{c|c}
\hline 原疾 患 & 耳鳴変化 \\
\hline 騒 音 性 難 聴 & 軽 快 \\
騒音 性 難 聴 & 軽 快 \\
二 エ 病 & 軽 快 \\
頭 部 外 㑑 後 遺 症 & 軽 快 \\
無 難 聴 性 耳 鳴 & 軽 快 \\
突 発 性 難 聴 後 遺 症 & 増 悪 \\
特 発 性 感 音 難 聴 & 増 悪 \\
原 因 不 明 感 音 難 聴 & 不 変 \\
原 因 不 明 感 音 難 聴 & 消 失 \\
原 因 不 明 感 音 難 聴 & 軽 快 \\
\hline
\end{tabular}

認めた。な拈 AP 潜時の変化は測定誤差範囲内 であった。

2) 耳鳴患者の蝸電図 AP

表 1 に対象患者の原疾患と自覚的な耳鳴変化 を示す。原疾患は騒音性難聴 2 例，メニエール 病 1 例, 頭部外傷後遺症 1 例, 無難聴性耳鳴 1 例, 突発性難聴後遺症 1 例, 特発性感音難聴 1 例, 原因不明感音難聴 3 例である.リドカイン 静注による耳鳴変化は突発性難聴後遺症と特発 性感音難聴の 2 例が増悪し, 原因不明の感音難 聴の 1 例が不変であったが，その他 7 例は消失

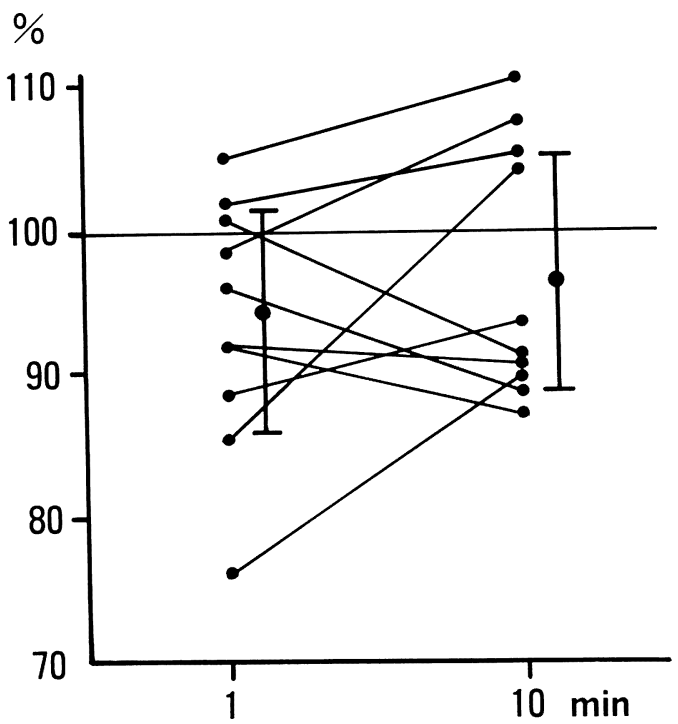

図 2 耳鳴患者の蝸電図 AP 振幅 リドカイン $2 \mathrm{mg} / \mathrm{kg}$ を静注. 静注前值を $100 \%$ とした相対的変化を示した。

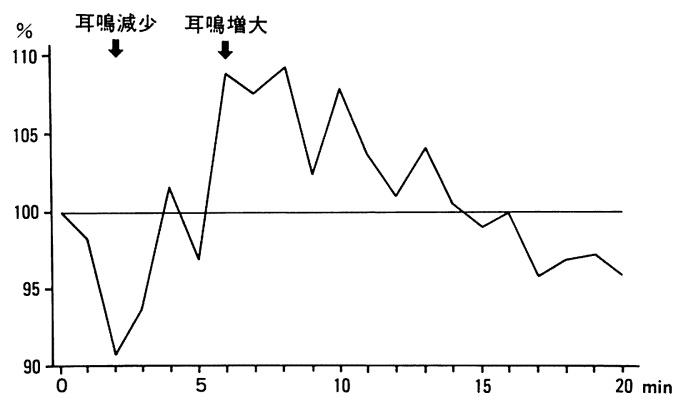

図 3 特発性感音難聴症例の AP 振幅と耳鳴の変化 
または軽快した（有効率70\%）。

蝸電図の測定結果はリドカイン静注前を 100 $\%$ とした相対的な変化を検討した．AP 潜時の 変化はモルモットと同様, 測定機器の䛊差範囲 内のわずかなものであった。

AP 振幅の变化は症例ごとに様々であり 10 例 全体では有意な変化を認めなかった $(\mathrm{P}>0.05)$. 個々の变化は多様であり静注 1 分後に 10 例中 7 例 (70\%) で AP 振幅が減少し，残り 3 例（30 \%）が増加した。

静注 10 分後は静注 1 分後に振幅が減少した 7

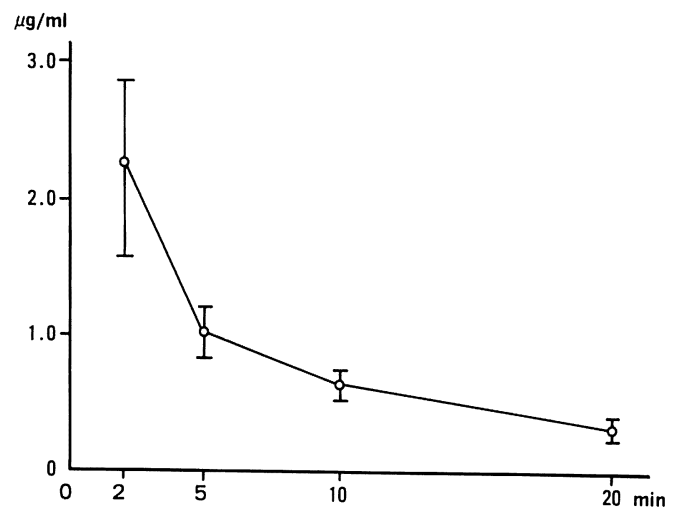

図 4 耳鳴患者の静脈血漿中リドカイン濃度 リドカイン $1 \mathrm{mg} / \mathrm{kg}$ を静注.

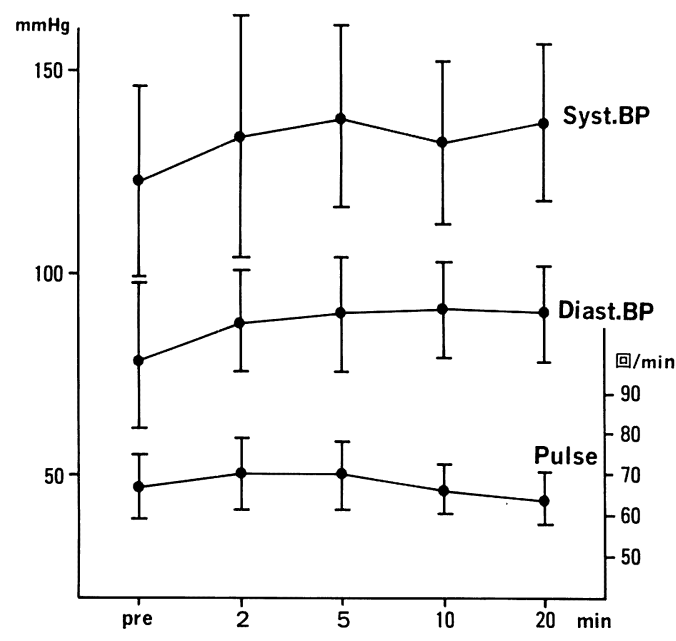

図 5 耳鳴患者の血圧 - 心拍数の変化 リドカイン $1 \mathrm{mg} / \mathrm{kg}$ を静注.
例中 4 例 $(57 \%)$ が 1 分後よりも増大し， 3 例 （43\%）はさらに減少した。また静注 1 分後増 大した 3 例中 2 例 $(67 \%)$ が10分後さらに増大 し，1例（33\%）は減少した。（図 2 )

その中で特発性感音難聴の一例は興味ある変 化を示した. 図 3 にこの症例の AP 振幅と耳鳴 の経時的変化を示す. この症例は $1 \mathrm{mg} / \mathrm{kg}$ の リドカインを静注した時, 耳鳴は増大のみ示し た. 今回 $2 \mathrm{mg} / \mathrm{kg}$ のリドカインを静注した場 合, AP 振幅は 1 分後から 3 分後まで最大 $10 \%$ 減少し， 6 分後から約14分後までは逆に約 $10 \%$ 増大した。この時の自覚的評価による耳鳴は, AP 振幅低下時に一時的に減少し, AP 振幅が 増大するとともに増大した。

3）耳鳴患者の静脈血漿中リドカイン濃度, IIII圧, 心拍数の測定結果

静脈血漿中リドカイン濃度は, 静注 2 分後の $2.26 \pm 0.68 \mu \mathrm{g} / \mathrm{ml}$ を最高とし 5 分後 $1.0 \pm$ $0.20 \mu \mathrm{g} / \mathrm{ml}, 10$ 分後 $0.63 \pm 0.12 \mu \mathrm{g} / \mathrm{ml}, 20$ 分後 $0.35 \pm 0.09 \mu \mathrm{g} / \mathrm{ml}$ と静注 5 分後までに急速に 低下した。（図 4 ）

血圧の変化は収縮期圧, 拡張期圧ともに静注 後に若干の上昇を認めたが有意差はなかった $(\mathrm{P}>0.05)$. 心拍数の変化も有意差はないが静 注 5 分後まで若干の増加を認めた $(\mathrm{P}>0.05)$.

(図 5 )

血圧，心拍数の測定結果はともにリドカイン $1 \mathrm{mg} / \mathrm{kg}$ が循環を抑制する所見を示さなかった。

\section{考察}

局所麻酔剤静注による耳鳴治療は Bárány (1935)1)が初めて報告し，Lewy2) がこれを追試 している. リドカインは Gejrot (1963)3) がメ = エール病発作の治療に初めて使用し，以後耳鳴 治療にも用いら机るようになった。本邦では安 田 (1973) ${ }^{4)}$ が報告して以来, 耳鳴とリドカイ ンの関係について数々の研究が行なわれている. 臨床的には生食水との二重盲検法5)6) をはじめ としてリドカイン静注の有効性が確認されてお り, 当科でも週 1 回の静注を 5 回を 1 クールと して施行する事により, 静注時の一過性の効果 
のみならず一部持続的, 長期的な効果も認めこ れを報告している7).

リドカイン静注の耳鳴抑制機序に関しては, 耳鳴の発現機序が確定していないこともあり, いまだ定説がないのが現状である。この中で Melding 8 ) が78人の耳鳴患者にリドカイン静注 を施行しコルチ器障害に伴う耳鳴に特に有効で あったとしているのが注目され，沖9)も同様な 結果を報告している. Meldingはコルチ器障害 による耳鳴は deafferentiation に伴ら聴覚路の 異常な興奮を原因としておこり, リドカインは この異常な興奮を抑制すると仮定している。ま た, Shea ${ }^{10)}$ はリドカインが抗㾏攣剤と同様の 作用 (post tetanic potentiation を減少させる作 用)により auditory pathway reflex arch の異常 興奮を遮断すると仮定している.この仮設に基 ついてリドカイン静注が有効である症例に対し てカルバマゼピン, ジフェニルヒダントイン, トカイナイド，バルプロ酸ナトリウムなどを投 与することが試みられている(1) -16).ささらに Vernon ${ }^{17)}$ は tinnitus synthesizer による耳鳴の 遮蔽 (Residual Inhibition) もリドカインと同様 の機序で蝸牛障害性耳鳴を抑制すると推定し, これに適応となる症例に対してマスカー療法を おこならことを提案している。

この蝸牛作用説を裏付けるかのごとく

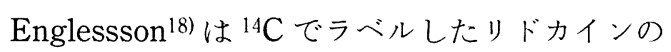
若干の蓄積をラットの蝸牛軸に認め, 電気生理 学的実験でもリドカイン静注によるネユ蝸牛神 経核聴ニューロンの自発放電の著明な減少19) やモルモット蝸牛神経単一線維の自発放電頻度 の減少20)が報告されている.

一方, 中枢性作用説はリドカインが epilepsy を止める作用を持ち，これが中枢性に働くとい ら仮説に基づき提唱されているようである。こ れを支持するものとして Javel21) はネコにリド カインを静注し ABR のすべての波形の潜時の

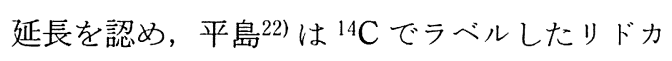
インをモルモットに静注し大脳, 小脳, 脳幹に 蓄積を多く認めたが蝸牛にはわずかしか認めな
かったとする Englesson と対立する報告をし ている.

リドカイン静注時の蝸電図測定は, 鈴木 ${ }^{23}$ がモルモットに $20 \mathrm{mg} / \mathrm{kg}$ のリドカインを投与 し $4 \mathrm{kHz}$ short tone burst 刺激で AP 振幅の一 過性の上昇とそれに続く減少を認め, AP 潜時 と $\mathrm{CM}$ には有意な変化を認めなかったとして いる. また 20-30 mg/kg の大量投与では AP 振 幅の高度な低下と AP 潜時の延長を示した群を 認め, この群の一部に ECG の高振幅, 徐波傾 向と血圧の一時的な低下を認めたという。

Majumdar 24) は耳鳴患者20例で生理的食塩水静 注後と $1.5 \mathrm{mg} / \mathrm{kg}$ のリドカイン静注後に蝸電 図を測定し，リドカイン投与後に AP 振幅の有 意な減少を認めている。 また井上25) は129例に $1.25 \mathrm{mg} / \mathrm{kg}$ のリドカインを投与し AP 潜時に 延長36例, 短縮 9 例, 不变 48 例, 計測不能 36 例 と多彩な変化を認めている。なお， AP 振幅に ついては精密な測定ができなかったという．

今回, 我々が行なった蝸電図 AP の測定では モルモットに 10-20 mg/kgのリドカインを静注 した場合, AP 振幅の一過性の減少とこれに続 く増加を認め, この減少と増加はグルコース単 独投与の場合には認めなかった。 耳鳴患者に 2 $\mathrm{mg} / \mathrm{kg}$ のリドカインを静注した場合は耳鳴改 善率は $70 \%$ と高かったが, AP の振幅の変化は 多様であり一定の有意な変化を認めなかった。 しかし，特発性難聴の一症例でモルモットと同 様, AP 振幅の減少とこれに続く増大を認め, 加えて耳鳴の減少と増大といら興味ある所見を 認めた。モルモットの AP 振幅の低下とこれに 続く増加は, リドカイン投与量が $10-20 \mathrm{mg} / \mathrm{kg}$ と大量であることから鈴木が報告した高度変化 群之同様, 循環系の抑制を受けた可能性が高い と推定される。

局所麻酔剤の循環系に及ぼす作用 ${ }^{29130)}$ は, 非 中毒量ではほとんど認めず，むしろ大脸皮質の 抑制シナプスが選択的に抑制されることにより 中枢性脱抑制がおこり軽度の血圧上昇, 心拍数 増加を生じるとされている。 また抗不整脈濃度 
(1.5〜 $5 \mu \mathrm{g} / \mathrm{ml})$ ではプルキニエ線維，心室筋の 域值上昇，伝導抑制が扣きるが心房は汪とんど 影響を受けないため心拍数，PQ 間隔は不変で あり，中毒量に近づくと収縮，心伝導系の抑 制，末梢血管の拡張が起こりショック，心停止 をきたすという。振戦, 悪寒, 多弁, 興奮, 痤 攣など中枢神経症状が発現する血中濃度につい ては Foldes ${ }^{31)}$ が囚人で調べ， $5.29 \pm 0.55$ $\mu \mathrm{g} / \mathrm{ml}$ と報告している，我々がリドカイン 1 $\mathrm{mg} / \mathrm{kg}$ 静注時に測定した血圧・心拍数の結果 では，有意ではないが中枢性脱抑制の機序に一 致した若干の上昇を認めた。また血中濃度は最 大の静注 2 分後においても $2.26 \pm 0.68 \mu \mathrm{g} / \mathrm{ml}$ と非中毒量であり，2 mg/kg を静注した蝸電図 測定時にも中枢神経症状の発現を認めなかった.

鈴木 ${ }^{23)}$ は $4 \mathrm{kHz}$ short tone burst で $\mathrm{AP}$ 振幅に一過性の増大を認めた原因として olivocochlear bundle の抑制による whole nerve action potential の脱抑制を仮定し，また耳鳴 患者で時に認める静注時の耳鳴の増大にもこれ が関与する可能性を示唆している，我々の経験 した特発性難聴の一例は, 静注直後 AP 振幅と 耳鳴が減少したのち AP 振幅および耳鳴の増大 を認めた。この機序として血中リドカイン濃度 の経時変化による神経インパルスの抑制機序の 変化も考号られる.すなわち静注直後には血中 リドカイン濃度が最高となるため whole nerve のインパルスが抑制され，濃度低下とともにリ ドカイン感受性の高い olivocochlear bundle の み抑制され，AP 振幅増大と耳鳴の増大が起こ るとも推定される。リドカインによる神経イン パルスの抑制は無髄神経が有髄神経よりもらけ やすく32), olivocochlear bundle を構成する線 維は無髄神経が多いことが知られている。しか

し，この考察はあくまで推論の域をでていない。 今回の蝸電図測定ではモルモットに 10-20 $\mathrm{mg} / \mathrm{kg}$ を静注した場合は循環系の抑制が避け られず，耳鳴患者に $2 \mathrm{mg} / \mathrm{kg}$ を静注した場合 には耳鳴の自覚変化から期待される汪どの蝸電 図所見を得ることは困難であった。今後は蝸電
図測定装置の精度を改善し， CM ・ SP を含め 低濃度リドカイン投与時のわずかな変化をとら えることと, olivocochlear bundle と耳鳴との 関係等についてさらに研究が進められることが 期待される.

$$
\text { まとめ }
$$

モルモットと耳鳴患者にリドカインの静注を 行ない, 以下の結論を得た。

1. モルモットへの $10-20 \mathrm{mg} / \mathrm{kg}$ の静注によ り AP 振幅の一過性の減少とこれに続く増大を 認めた。

2. 耳鳴患者への $2 \mathrm{mg} / \mathrm{kg}$ の静注では $70 \%$ に耳鳴の軽快を認めたが，AP 振幅に有意な変 化を認めなかった。

3. 耳鳴患者への $1 \mathrm{mg} / \mathrm{kg}$ の静注では静脈 血漿中濃度は静注 2 分後に最大 $2.26 \pm 0.68$ $\mu \mathrm{g} / \mathrm{ml}$ であり，血圧・心拍数に抑制を認めなか った.

\section{参考文献}

1) Bárány R : Die Beeinflussung des Ohrensausens durch intravenös injizierte Lokalanästhetica. Acta Otolaryngol $23: 201 \sim 203,1935$.

2) Lewy RB : Treatment of tinnitus aurium by the intravenous use of local anesthetic agents. Arch Otolaryngol 25 : 178 183, 1937.

3) Gejrot $T:$ Intravenous xylocaine in the treatment of attacks of Menière's disease. Acta Otolaryngol Suppl 188: 190 195, 1963.

4) 安田宏一, 西田之昭, 池田雄祐: 耳鳴に対する 局所麻酔剂静注の効果. 耳喉 $45: 97 \sim 100,1973$.

5) Israel JM, Connelly JS, McTigue ST, et al : Lidocaine in the treatment of tinnitus aurium. Arch Otolaryngol 108 : 471 473, 1982.

6) Duckert LG and Rees TS : Treatment of tinnitus with intravenous lidocaine: a double blind randomized trial. Head Neck Surg 91 : 550 555, 1983.

7）上田晋介, 麻生 伸, 吉田行夫, 他: キシロカ インによる耳鳴治療. Audiology Japan 31： 117 122, 1988.

8) Melding PS, Godey RJ and Thorne PR : The use of intravenous lignocaine in the diagnosis 
and treatment of tinnitus. J Laryngol Otol $92: 115 \sim 121,1978$.

9）沖勉, 朝隅真一郎, 村塚幸穂: 内耳障害に よっておこった耳鳴のキシロカイン静注による 変化. Audiology Japan 25 : 581 582, 1982.

10) Shea JJ and Harell M : Management of tinnitus aurium with lidocaine and carbamazepine. Laryngoscope $88: 1477 \sim 1484,1978$.

11) Shea JJ and Emmett JR : The medical treatment of tinnitus. J Laryngol Otol Suppl 4 : 130 138, 1981.

12) Goodey RJ : Drugs in the treatment of tinnitus. Tinnitus (Ciba Foundation symposium 85). pp 263 265, Pitman Press, London, 1981.

13) Emmett JR and Shea JJ : Treatment of tinnitus with tocainide hydrochrolide. Otolaryngol Head Neck Surg 88 : 442 446, 1980 .

14) Emmett JR : Drugs and tinnitus. Tinnitus (Ciba Foundation symposium 85). pp 275 276, Pitman Press, London, 1981.

15) Melding PS and Goodey RJ : The treatment of tinnitus with oral anticonvulsants. J Laryngol Otol $93: 111 \sim 122,1979$.

16）斉藤武久, 黑川泰資, 劑藤 等, 他：耳鳴に対 するバルプロ酸ナトリウムの効果. Audiology Japan $28: 571 \sim 572,1985$.

17) Vernon $\mathrm{J}:$ Attempts to relieve tinnitus. J Am Audiol Soc 2 : 124 131, 1977.

18) Englesson $S$, Larsson B, Lindquist NG, et al : Accumuration of ${ }^{14} \mathrm{C}$-lidocaine in the inner ear. Acta Otolaryngol 82 : 297 300, 1976.

19）棚橋汀路, 服部 环, 森 正博: 耳鳴の生理学 的研究. 基礎耳科 $15: 375 \sim 378,1984$.

20）松島純一, 村上 進, 寺山吉彦: 蝸牛神経単一 線維の自発放電に対する xylocaine 静注の影響 について。目曼 $87: 1309,1984$.

21) Javel E, Mouney DF, McGee J, et al : Auditory brainstem responses during systemic infusion of lidocaine. Arch Otolaryngol 108: 71 76, 1983.

22）平島健二郎, 朝隅真一郎：程酸リドカインの体 内分布および動態. 基礎耳科 $14: 97 \sim 99,1983$.

23）鈴木 衛, 土田昌也, 夜陣紘治：キシロカイン 静注の ABR, 蝸電図に及ぼす变化. Audiology Japan $26: 636 \sim 646,1983$.

24) Majumdar B, Manson SM and Gibbin KP : An electrocochleographic study of the effects of lignocaine on patients with tinnitus. Clin Otolaryngol $8: 175 \sim 180,1983$.

25）井上秀朗：塩酸リドカイン静注の蝸電図に対す る影響. 耳展 $29: 627 \sim 640,1986$.

26）竹田泰三：メニエール病の聴覚に関する実験的 研究. 耳鼻臨床 74 増 $5: 2507 \sim 2561,1981$.

27）上田晋介，麻生 伸，武田精一，他：電極位置 の違いによる蝸電図波形の検討.Audiology Japan $29: 491 \sim 492,1986$.

28）水越鉄理：めまい.平衡障害の診断と治療．第 89回日耳鼻宿題報告（金沢）。現代医療社，東 京, 1988.

29) Covino BG : Local anesthesia (Part one). New EJ Med 286 : 975 983, 1983.

30) Covino BG : Local anesthesia (Part two). New EJ Med 286 : 1035 1042, 1983.

31) Foldes FF, Molley R, McNall PG, et al : Comparison of toxicity of intravenously given local anesthetic agents in man. JAMA $172: 1493 \sim$ 1498, 1960.

32) Jung RH and Nace RA : Nerve inpulse conduction during intravenous lidocaine injection. Anesthesiology $29: 22 \sim 28,1968$.

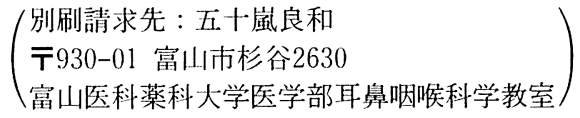

